\title{
Proteomic Analysis of Bacterial Expression Profiles Following Exposure to Organic Solvent Flower Extract of Melastoma candidum D Don (Melastomataceae)
}

\author{
Fai-Chu Wong ${ }^{1,2 *}$, Ann-Li Yong ${ }^{2}$, Kooi-Mow Sim ${ }^{1,2}$, Hean-Chooi Ong ${ }^{3}$ and Tsun- \\ Thai Chai ${ }^{1,2}$ \\ ${ }^{1}$ Centre for Biodiversity Research, ${ }^{2}$ Department of Chemical Science, Faculty of Science, Universiti Tunku Abdul Rahman, \\ 31900 Kampar, ${ }^{3}$ Institute of Biological Sciences, Faculty of Science, University of Malaya, 50603 Kuala Lumpur, Malaysia \\ *For correspondence: Email: wongfc@utar.edu.my
}

\begin{abstract}
Purpose: To identify potential antibacterial protein targets following exposure to Melastoma candidum extract.

Methods: Plant extracts were prepared using sequential extraction method. Denaturing gel electrophoresis and MALDI TOF-TOF MS protein sequencing were used to identify differentialexpressed bacterial proteins. 96-well microplate method was used to determine the minimum inhibitory concentration (MIC) values. Thin layer chromatography (TLC) bio-autobiography and gaschromatography-mass spectrometry (GC-MS) were performed to determine the phytochemicals in the active fraction.

Results: Five differentially expressed bacterial proteins (four from Escherichia coli and one from Staphylococcus aureus), were identified via proteomic approach. Among the bacterial proteins identified, glutamate decarboxylase, elongation factor-Tu and $\alpha$-hemolysin are especially noteworthy, as they are implicated in critical bacterial pathways pertaining to survival in acidic environment, protein translation and virulence, respectively. Additionally, we tested and reported the minimum inhibition concentrations of different $M$. candidum fractions and gas chromatography-mass spectrometry GC-MS analysis of the active fraction.

Conclusion: Glutamate decarboxylase, elongation factor-Tu and $\alpha$-hemolysin represent potential antibacterial targets.
\end{abstract}

Keywords: Escherichia coli, Staphylococcus aureus, Melastoma candidum, Glutamate decarboxylase, Elongation factor-Tu, $\alpha$-Hemolysin, Protein expression

\begin{abstract}
Tropical Journal of Pharmaceutical Research is indexed by Science Citation Index (SciSearch), Scopus, International Pharmaceutical Abstract, Chemical Abstracts, Embase, Index Copernicus, EBSCO, African Index Medicus, JournalSeek, Journal Citation Reports/Science Edition, Directory of Open Access Journals (DOAJ), African Journal Online, Bioline International, Open-J-Gate and Pharmacy Abstracts
\end{abstract}

\section{INTRODUCTION}

As the world is facing increasing cases of multidrug-resistant bacteria, there is an urgent need to search for novel antibacterial compounds. Besides synthetic inhibitors, potential sources of antibacterial compounds include those derived from natural products such as medicinal plants. Nonetheless, the inhibition mechanisms of many antibacterial phytochemicals remain elusive. Frequently, it is unclear which bacterial pathways or enzymes are being targeted.

In the efforts to discover potential therapeutic targets, as well as seeking for better understanding of their inhibition mechanisms, studies have been conducted to investigate the 
effects of antibacterial agents on bacterial gene expressions [1,2]. For instance, using proteomic analysis methods, differentially expressed proteins have been identified in Gram-positive Staphylococcus aureus following exposure to silver (Ag), an active antibacterial agent incorporated in many healthcare products [3]. A similar approach has also been applied using plumbagin, an antimicrobial compound found in many medicinal plants [4]. Upon exposure to plumbagin, differentially expressed proteins from Gram-negative Escherichia coli have also been pinpointed.

Melastoma candidum (Melastomataceae family) is a medicinal plant distributed in the tropical and subtropical areas, including Southeast Asia. Traditionally, this plant has been used to eliminate stasis, toxin cleansing and traumatic injury treatment [5]. Studies have indicated the presence of bioactivities, such as antihypertension [6], free radical scavenging activities and monoamine oxidase inhibition activities in this plant extract [7]. Recent research works have also revealed $M$. candidum's broadspectrum antibacterial activities [5,8]; however, its inhibition mechanism remains unclear.

In this paper, we fractionated $M$. candidum extracts into different organic solvents and determined their corresponding minimum inhibition concentrations [9]. In our proteomic work, we identified and reported five differentially expressed bacterial proteins (four from E. coli and one from $S$. aureus), following exposure to M. candidum extracts. To the best of our knowledge, this represents the first time such bacterial protein targets are being reported in literature, in conjunction with $M$. candidum treatment. Additionally, we performed GC-MS analysis to study phytochemicals present in the active fraction. Through our works, we hope to shed light on some of the possible antibacterial therapeutic targets. Further works in this direction could potentially lead to the discovery and optimization of target-specific antibacterial agents.

\section{EXPERIMENTAL}

\section{Preparation of plant extracts}

M. candidum were collected from April to June of 2012. The plant species was authenticated by Professor Dr. Hean-Chooi Ong at the Institute of Biological Sciences, University of Malaya, Malaysia. Voucher specimen (voucher no: MHR2012-003) was deposited at Faculty of Science,
Universiti Tunku Abdul Rahman. The plant materials (flowers) were dried in an oven at 40 ${ }^{\circ} \mathrm{C}$ for $48 \mathrm{~h}$ or until constant weight was observed. Dried plant sample was then pulverized, followed by sequential extractions using hexane, ethyl acetate, acetone, methanol and distilled water. Supernatants were then filtered, concentrated and stored in $-20{ }^{\circ} \mathrm{C}$ until testing.

\section{Bacteria strains and culture conditions}

A total of seven bacterial strains (Gram-negative: E. coli ATCC 25922, E. coli ATCC 35218, Pseudomonas aeruginosa ATCC 27853; Grampositive: $M$. luteus ATCC 4698, MRSA ATCC 33591, S. aureus ATCC 6538, S. aureus ATCC 25923,) were tested in this study. Bacteria strains were cultured overnight in Luria-Bertani broth, using autoclaved conical flasks placed in a $37{ }^{\circ} \mathrm{C}$ orbital shaking incubator, with constant shaking (200 rpm). Bacterial cultures were adjusted to 0.5 - 1 McFarland standard before used in subsequent experiments.

\section{Minimum inhibitory concentration (MIC) assay}

MIC assays were performed using the published protocol with modifications [10,11]. Briefly, a final bacterial inoculum of $5 \times 10^{5} \mathrm{cfu} / \mathrm{ml}$ was prepared using Mueller-Hinton Broth (MHB) and aliquoted into a 96-well sterile microtitre plate. Plant extracts were added into the first row of wells, and serial dilutions were performed to achieve final concentrations of $50,25,12.5,6.3$, $3.1,1.6,0.8$ and $0.4 \mathrm{mg} / \mathrm{ml}$. The sealed plate was then incubated at $37^{\circ} \mathrm{C}$. After $18-24 \mathrm{~h}, 20$ $\mu \mathrm{l}$ of $0.4 \mathrm{mg} / \mathrm{ml}$ of $\mathrm{p}$-iodonitrotetrazolium chloride (Fisher Scientific) was added to each well, followed by $30 \mathrm{~min}$ of incubation at $37^{\circ} \mathrm{C}$. Color changes to pink were observed. The lowest sample concentration whereby no color change was observed and recorded as the MIC value. The reported MIC values represented average values of three identical replicate trials. Commercial ampicillin and kanamycin (SigmaAldrich) were used as positive controls. Sterility control and solvent control were also included in the MIC assays.

\section{Isolation of bacterial protein for SDS-PAGE analysis}

Bacterial cultures were treated with $2-6 \mathrm{mg} / \mathrm{ml}$ of filtered plant extracts, and equivalence of solvents alone were used in negative controls. Bacterial cultures were then allowed to grow at $37{ }^{\circ} \mathrm{C}$ with constant shaking (200 rpm). At the intended time intervals (5, 30, 60 and $90 \mathrm{~min}), 20$ 
$\mathrm{ml}$ of cultures were collected, and bacterial cells were harvested by refrigerated centrifugation at $9000 \mathrm{rpm}$ for $10 \mathrm{~min}$. Bacterial proteins were then extracted from the cell pellets and culture supernatants, using bacterial protein extraction reagent (Thermo Scientific) and ammonium sulfate precipitation.

\section{SDS-PAGE gel electrophoresis and protein sequence analysis}

SDS-PAGE gel electrophoresis was performed using $12 \%$ resolving gel [1.5 M Tris- $\mathrm{HCl}, \mathrm{pH} 8.8$ (Bio Basic Canada, Inc), $10 \%$ SDS (Fisher Scientific), $40 \%$ bis-acrylamide] and $4 \%$ stacking gel [0.5 M Tris-HCl ( $\mathrm{pH} 6.9), 10 \%$ SDS, $40 \%$ bis-acrylamide]. Before being loaded into the wells, bacterial proteins were treated with dithiothreitol (DTT) and boiled. For ease of molecular weight estimation and comparison, protein ladder (Spectra Multicolor Broad-Range Protein Ladder, Thermo Scientific) was loaded onto each gel. The SDS-PAGE gels were run using constant electric current $(135 \mathrm{mV})$ until the bromophenol blue dye front reached the bottom of the gel plate. Protein gels were then stained with Coomassie Brilliant Blue R-250 (Fisher Scientific) staining solution for an hour, followed by overnight destaining in distilled water. Differentially expressed protein bands were then excised using sterile razor blades and subjected to analysis by MALDI TOF-TOF mass spectrometry (4800 Proteomics Analyzer, AB Sciex) (Proteomics International, Perth, Australia). Spectra were analyzed using Mascot sequence matching software (Matrix Science) with Ludwig NR Database to identify the proteins of interest.

\section{Thin layer chromatography bioautobiography}

(TLC)

TLC bioautobiography was performed as previously described [12], with modification. Briefly, $0.2 \mathrm{mg}$ of the plant extract (methanol fraction) was spotted at $1.5 \mathrm{~cm}$ from the base of a TLC plate (Silica Gel 60 F254, Merck) and developed using a 9:1 methanol:chloroform mobile phase. Two duplicate TLC plates were run concurrently: Plate $A$ was used for bioautography, while Plate B was used to extract the spots containing antibacterial compounds. Plate A was developed as described above and then placed in a sterile petri dish. Next, $0.1 \mathrm{ml}$ of bacteria culture $\left(1 \times 10^{6} \mathrm{cfu} / \mathrm{ml}\right)$ was mixed into $10 \mathrm{ml}$ of nutrient agar, and the agar was distributed over Plate A. Once the agar solidified, Plate A was incubated at $37{ }^{\circ} \mathrm{C}$. After $24 \mathrm{~h}$ of incubation, $0.2 \mathrm{mg} / \mathrm{ml}$ of $\mathrm{p}$-iodonitrotetrazolium violet solution was sprayed onto the agar. Clear zone on the agar indicated phytochemical fraction with bacterial inhibitory activity. Corresponding spot was determined on Plate B, and the silica gel was extracted with a spatula. Bioactive compounds were eluted from the silica gel using methanol. After centrifugation and subsequent filtration, the supernatant was then subjected to GC-MS analysis.

\section{Gas chromatography-mass spectrometry (GC-MS) analysis of TLC spots}

TLC spots were analyzed by gas chromatography equipped with mass spectrometry (GCMS-QP2010 Plus, Shidmadzu). The column temperature was set to $110{ }^{\circ} \mathrm{C}$ for $2 \mathrm{~min}$, then increased to $200{ }^{\circ} \mathrm{C}$ (at the rate of $10{ }^{\circ} \mathrm{C} / \mathrm{min}$ ), and finally increased to $280{ }^{\circ} \mathrm{C}$ (at the rate of 5 ${ }^{\circ} \mathrm{C} / \mathrm{min}$ ) and held constant for $9 \mathrm{~min}$. The injector temperature was set to $250{ }^{\circ} \mathrm{C}$ (split mode with the ratio adjusted to $20: 1$, with injection volume of $3 \mathrm{ul}$ ). The flow rate of the carrier gas (helium) was set to $1 \mathrm{ml} / \mathrm{min}$, and the ion source was set to $280{ }^{\circ} \mathrm{C}$. The total running time of the gas chromatography was $36 \mathrm{~min}$. The mass spectra were obtained from the range of $\mathrm{m} / \mathrm{e} 40$ to 700 . The identities of the samples were determined by comparing the mass spectra with NIST Gas Chromatography Library database.

\section{Statistical analysis}

Data were reported as mean \pm standard errors, obtained from three replicate trials. Statistical analysis was performed using SAS (Version 9.2). Data were analyzed using ANOVA test, and significant differences between means were separated using Fisher's Least Significant Difference test at $p<0.05$.

\section{RESULTS}

In our work, the $M$. candidum was fractionated into organic solvents with different polarities and tested for their inhibition activities against a total of seven bacterial strains (Table 1). Bacterial inhibition activities were observed with $M$. candidum extracts fractionated into water, methanol and acetone. No inhibition was observed with the hexane extract, whereas ethyl acetate extract was found to inhibit only one strain of bacteria tested. The strongest bacterial inhibition activity was observed with methanol extract, followed by water and acetone extracts. The strong inhibition activities of methanol extract were indicated by its low MIC values $(0.31-5 \mathrm{mg} / \mathrm{ml})$. 
Table 1: Minimum inhibitory concentration (MIC, $\mathrm{mg} / \mathrm{ml}$ ) of different $M$. candidum fractions, against Gram-positive and Gram-negative bacterial strains; ampicillin and kanamycin were included as the positive controls

\begin{tabular}{|c|c|c|c|c|c|c|}
\hline \multirow{3}{*}{ Bacterial strain } & \multicolumn{6}{|c|}{ Minimum inhibition concentration ( $\mathrm{mg} / \mathrm{ml})$} \\
\hline & \multicolumn{4}{|c|}{ Organic solvent fractionation } & \multicolumn{2}{|c|}{ Antibiotic control } \\
\hline & $\begin{array}{l}\text { Ethyl } \\
\text { acetate }\end{array}$ & Acetone & Methanol & Hot water & Ampicillin & Kanamycin \\
\hline \multicolumn{7}{|l|}{ Gram-negative } \\
\hline E. coli 25922 & - & - & $5.00 \pm 0^{b}$ & $12.50 \pm 0^{a}$ & $0.08 \pm 0^{c}$ & $0.04 \pm 0^{d}$ \\
\hline E. coli 35218 & - & - & $2.50 \pm 0^{b}$ & $8.30 \pm 2.10^{a}$ & - & $0.04 \pm 0^{b}$ \\
\hline $\begin{array}{l}P . \text { aeruginosa } \\
27853\end{array}$ & - & - & $5.00 \pm 0^{a, b}$ & $8.30 \pm 2.10^{a}$ & - & $2.50 \pm 0^{b}$ \\
\hline \multicolumn{7}{|l|}{ Gram-positive } \\
\hline M. luteus 4698 & - & - & - & $0.80 \pm 0^{b}$ & $1.22 \pm 0^{a}$ & - \\
\hline MRSA 33591 & $5.00 \pm 0^{a}$ & $3.44 \pm 0^{b}$ & $0.31 \pm 0^{f}$ & $1.56 \pm 0^{c}$ & $1.04 \pm 0^{\mathrm{d}}$ & $0.63 \pm 0^{\mathrm{e}}$ \\
\hline S. aureus 25923 & - & - & $1.25 \pm 0^{b}$ & $6.30 \pm 0^{a}$ & $0.02 \pm 0^{c}$ & - \\
\hline S. aureus 6538 & - & $4.17 \pm 0.83^{\mathrm{a}}$ & $0.63 \pm 0^{\mathrm{b}, \mathrm{c}}$ & $2.30 \pm 0.80^{a, b}$ & $0.02 \pm 0^{c}$ & - \\
\hline
\end{tabular}

Data are reported as mean \pm SE values $(n=3)$. Different super indexes indicate significantly different mean values within a row, determined by the Fisher's Least Significant Difference (LSD) test $(p<0.05)$

Table 2: Summary of protein identification of differentially expressed proteins using MALDI TOF-TOF MS. Protein bands (a to e) labeled as in Figures 1 and 2

\begin{tabular}{llllll}
\hline $\begin{array}{l}\text { Protein } \\
\text { band }\end{array}$ & $\begin{array}{l}\text { Protein } \\
\text { size } \\
\text { (in aa) }\end{array}$ & $\begin{array}{l}\text { No. of peptide } \\
\text { sequences } \\
\text { identified }\end{array}$ & $\begin{array}{l}\text { No. of amino } \\
\text { residues } \\
\text { identified }\end{array}$ & $\begin{array}{l}\text { Sequence } \\
\text { covered (\%) }\end{array}$ & Annotation \\
\hline A & 728 & 14 & 167 & 22.9 & Formate C-acetyltransferase \\
B & 476 & 10 & 113 & 23.7 & Glutamate Decarboxylase \\
C & 471 & 13 & 132 & 28.0 & Tryptophanase \\
D & 394 & 9 & 107 & 27.2 & Elongation Factor Tu 2 \\
E & 322 & 7 & 62 & 19.3 & a-Hemolysin \\
\hline
\end{tabular}

Next, by using proteomic approach, we aimed to identify differentially expressed bacterial proteins. In this effort, we focused on using two bacterial strains as the models, with representatives from Gram-negative (E. coli 35218) and Gram-positive (S. aureus 6538) bacteria. Following treatment with the $M$. candidum extract, bacterial cellular proteins were extracted and prepared using Bacterial Protein Extraction Reagents (Thermo Scientific) and ammonium sulfate precipitation. In the negative control, $M$. candidum extract was substituted with solvent alone as treatment. Purified bacterial proteins were then separated on denaturing polyacrylamide electrophoresis gels. Figure 1a showed the protein expression profile of $E$. coli at different time intervals, following exposure to $M$. candidum extract. Here, a total of four differentially expressed bacterial proteins (as indicated by letters a to $d$ ) were identified, excised and subjected to analysis by MALDI TOF-TOF mass spectrometer. The identities and characteristics of these proteins were summarized and reported in Table 2 .

Additionally, in order to determine the effects of M. candidum extract on the bacterial secretomics profiles, we resolved to use ammonium sulfate precipitation to isolate bacterial proteins secreted into the culture mediums, upon exposure to $M$.

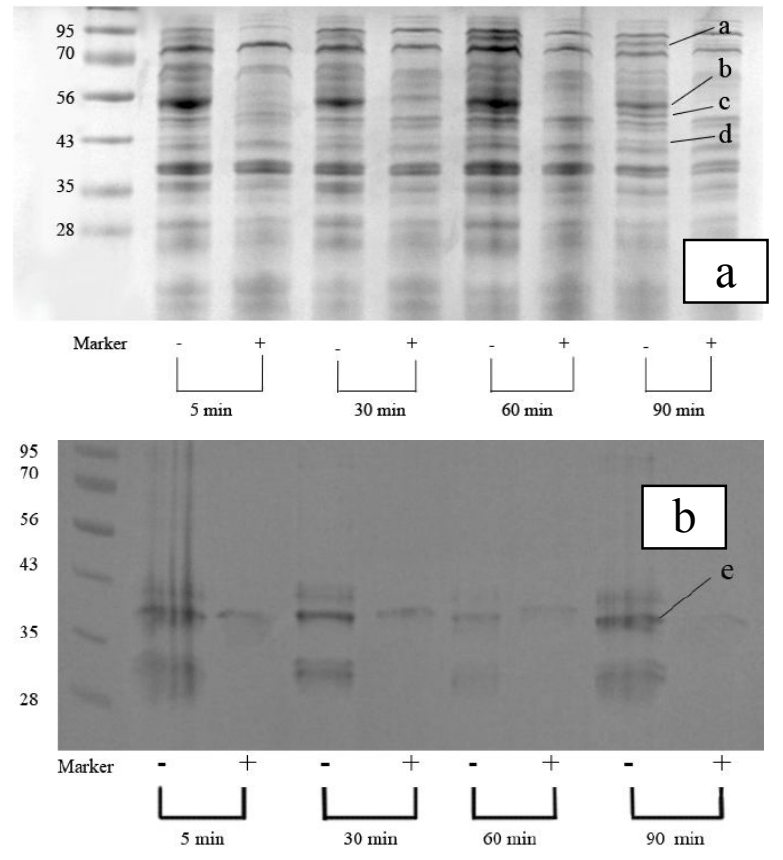

Figure 1: Protein expression profiles of (a) E. coli and (b) S. aureus, at time intervals of 5, 30, 60, $90 \mathrm{~min}$, following exposure to $M$. candidum extract. (-) and (+) indicated the absence or presence of $M$. candidum extract in bacterial culture medium, respectively. Labels (a to e) indicate differentially expressed protein bands selected for MALDI TOF-TOF MS sequence analysis 
M. candidum extract. Here, a differentially expressed protein band of approximately 35 to $43 \mathrm{KDa}$ was identified from the $S$. aureus culture medium (Figure 1b). The protein was excised and subjected to sequence determination by MS. Based on protein sequencing result, the identity of this protein was determined to be $\alpha$-hemolysin (a bacterial exotoxin protein)(Table 2). We also attempted, without success, to identify differentially expressed exoprotein from other bacterial strains, following exposure to $M$. candidum extract (data not shown). Lastly, we used GC-MS analysis to determine the phytochemicals present in the $M$. candidum extract. From the GC spectrum, seven major peaks were identified (Figure 2). Peaks 1 to 7 were selected and subjected to MS analysis. The identities and characteristics of these peaks were determined and summarized in Table 3.

\section{DISCUSSION}

Since the medieval age, medicinal plants have been utilized by different ethnic groups for assorted medicinal purposes, including but not limited to antibacterial applications. Recent advances in analytical science have enabled the identification of an ever expanding library of plant-derived bioactive compounds, noticeably those with antibacterial activities. These plantderived secondary metabolites are of a diverse chemical nature, including different derivatives of phenolic acids, flavonoids, alkaloids and terpenoids compounds. Yet, relatively few studies have focused on illustrating and explaining how these medicinal plants exert their bacterial inhibitory activities. In most cases, it remains elusive which bacterial enzymes or pathways are actually affected by these antibacterial medicinal plants.

It is hoped that with more knowledge gained regarding the antibacterial mechanisms of these medicinal plants, potential therapeutic targets in bacteria could be revealed. The revelation of these novel targets could facilitate the design and enhancement of powerful antibacterial agents. This sure will be welcoming news in a

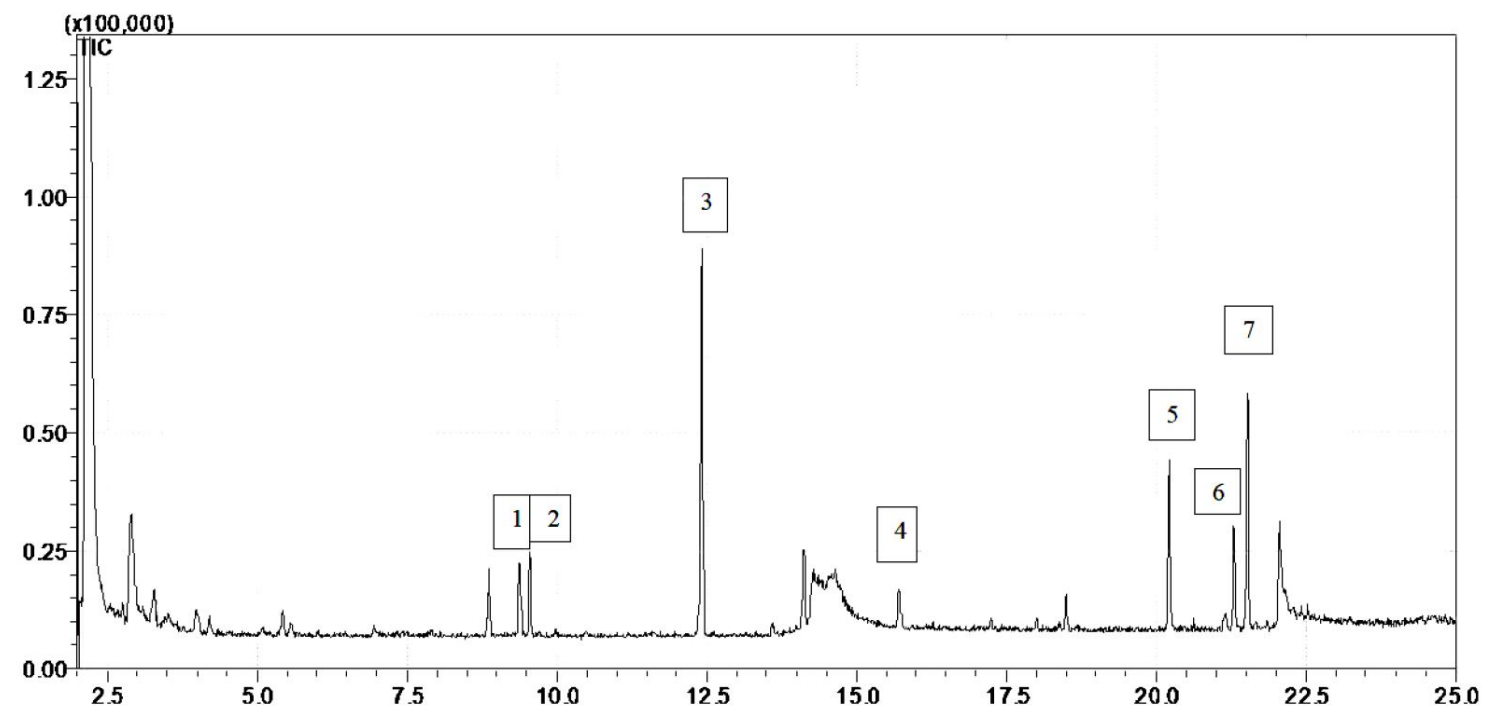

Figure 2: GC analysis of the active fraction of M. candidum methanol extract. Major peaks (compounds 1 to 7 ) were selected for further analysis with MS

Table 3: Major chemical compounds identified from the active fraction of $M$. candidum methanol extract by GCMS

\begin{tabular}{llllll}
\hline $\begin{array}{l}\text { Peak } \\
\text { no. }\end{array}$ & $\begin{array}{l}\text { Retention } \\
\text { time }(\mathbf{m i n})\end{array}$ & Name of compounds & $\begin{array}{l}\text { Molecular } \\
\text { formula }\end{array}$ & $\begin{array}{l}\text { Molecular } \\
\text { weight }\end{array}$ & $\begin{array}{l}\text { Purity } \\
(\%)\end{array}$ \\
\hline 1 & 9.41 & Butanoic acid, butyl ester & C8H6O2 & 134 & 80 \\
2 & 9.54 & 2-Heptanamine, 5-methyl & C8H19N & 129 & 80 \\
3 & 12.44 & Phenol, 2,4-bis(1,1-dimethylethyl) & C14H22O & 206 & 90 \\
4 & 15.73 & 1-Propanone, 2-amino-1-phenyl & C9H11NO & 149 & 79 \\
5 & 20.23 & 1-Butyl 2-(2-ethylhexyl) phthalate & C20H30O4 & 334 & 85 \\
6 & 21.37 & Hexadecanoic acid, 15-methyl, methyl ester & C18H36O2 & 284 & 82 \\
7 & 21.54 & $\begin{array}{l}\text { Benzenepropanoic acid, 3,5-bis(1,1- } \\
\text { dimethylethyl)-4-hydroxy, methyl ester }\end{array}$ & C18H28O3 & 292 & 79 \\
\hline
\end{tabular}


world faced with increasing cases of multi-drug resistant bacteria.

In our study, we chose to focus on M. candidum, a medicinal plant with broad-spectrum antibacterial activities. In general, it is more challenging to inhibit Gram-negative bacteria, as they are protected by the presence of outer membranes [13] and efflux pumps [14]. Interestingly, the $M$. candidum was found to inhibit both Gram-negative and Gram-positive bacteria, including $E$. coli, $P$. aeruginosa and MRSA. Our fractionation and MIC results suggested that the antibacterial compounds in $M$. candidum extract may most likely be those of the polar family, as the strongest activities were observed with aqueous and methanol fractions.

In our GC-MS analysis of the methanol fraction, a total of seven compounds were identified. Literature search revealed that Compound 3 (phenol, dimethyl) [15] and Compound 6 (hexadecanoic acid, methyl ester) [15-17] have previously been reported with antibacterial activities. Meanwhile, a closely related derivative (hexadecanoic acid, ethyl ester), fractionated using ethanol from Brazilian M. subsericea, was reported with antibacterial activities in a separate study [18]. The bromo derivative of Compound 1 (butanoic acid, butyl ester) has also been tested with antibacterial activities [19]. In addition, the presence of Compound 5 (phthalate) has previously been reported in the aerial parts of $B$. retusa, [20] and C. serrata [21]. Both of these plant species demonstrated inhibitory activities against $E$. coli, $S$. aureus and $P$. aeruginosa. Interestingly, synthetic derivatives of Compound 4 (1-propanone) has previously been reported with inhibitory activities against $E$. coli and $S$. aureus [22,23].

In our proteomic analysis, a total of five differentially expressed bacterial proteins were identified. To the best of our knowledge, this represents the first time such bacterial protein targets are being reported in literature, upon exposure to $M$. candidum extract. Formate $c-$ acetyltransferase is an enzyme involved in bacterial glucose and pyruvate metabolism [24], while glutamic acid decarboxylase (GAD) is utilized by bacteria to counteract the influx of protons from acidic environment, [25]. This feature of GAD enables the enteric bacteria such as $E$. coli to survive in the acidic environment of animal stomach. Interestingly, the expression level of elongation factor Tu (EF-Tu) was also affected by $M$. candidum. As EF-Tu interacts specifically with tRNAs during the protein elongation process, it is tempting to speculate that $M$. candidum extract may exert its inhibitory action via the bacterial protein translation pathway. This discovery is especially exciting considering that the protein translation process is critically essential to the bacteria survival, and it is highly conserved across different species of bacteria. [26]. It remains to be determined whether $M$. candidum extract affected EF-Tu in a similar mechanism as kirromycin, a commercial antibiotic targeting the bacterial EF-Tu $[27,28]$. Lastly, we also detected reduced a-hemolysin expression in the growth medium of $S$. aureus. $\alpha-$ Hemolysin is reported as a pore-forming exotoxin secreted by many pathogens, and it targets the host immune cells [29]. Multiple studies have also indicated the roles of this exotoxin in tissue barrier disruption and the subsequent lethal infection [30].

\section{CONCLUSION}

Our study has identified five bacterial proteins with reduced expression levels, upon treatment with $M$. candidum extract. Three of these bacterial proteins are especially noteworthy as potential therapeutic targets, namely GAD, EFTu and $\alpha$-hemolysin. Inhibition of these bacterial targets may likely prove fatal to the invading bacterial strains, by rendering the bacteria vulnerable in acidic environment (human stomach), unable to replicate (by blocking the translation pathway) and reduced virulence (by repressing the expression of membranedamaging exotoxin), respectively. Currently, it remains unclear how the bioactive compounds from $M$. candidum influenced these bacterial proteins. To complicate matters further, the question of whether one compound inhibited the bacteria single-handedly or a group of these compounds worked synergistically needs to be addressed too. It is hoped that further works in this direction could potentially lead to the discovery of effective therapeutic agents similar to that or better than kirromycin.

\section{ACKNOWLEDGEMENT}

This research was supported by Toray Science Foundation (Japan) and UTAR Research Fund (UTARRF), Malaysia.

\section{REFERENCES}

1. Martínez JL. Antibiotics and antibiotic resistance genes in natural environments. Science 2008; 321(5887): 365367. 
2. Gmuender H, Kuratli K, Di Padova K, Gray CP, Keck W, Evers $S$. Gene expression changes triggered by exposure of Haemophilus influenzae to Novobiocin or ciprofloxacin: Combined transcription and translation analysis [1]. Genome Res. 2001; 11(1): 28-42.

3. Smith A, McCann M, Kavanagh K. Proteomic analysis of the proteins released from Staphylococcus aureus following exposure to $A g(l)$. Toxicol. In Vitro 2013; 27(6): 1644-1648.

4. Chen JW, Sun CM, Sheng WL, Wang YC, Syu Jr W. Expression analysis of up-regulated genes responding to plumbagin in Escherichia coli. J. Bacteriol. 2006; 188(2): 456-463.

5. Wang YC, Hsu HW, Liao WL. Antibacterial activity of Melastoma candidum D. Don. LWT--Food Sci. Technol. 2008; 41(10): 1793-1798.

6. Cheng JT, Hsu FL, Chen HF. Antihypertensive principles from the leaves of Melastoma candidum. Planta Med. 1993; 59(5): 405-407.

7. Lee $M H$, Lin RD, Shen LY, Yang LL, Yen KY, Hou WC. Monoamine oxidase $B$ and free radical scavenging activities of natural flavonoids in Melastoma candidum D. Don. J. Agric. Food Chem. 2001; 49(11): 5551-5555.

8. Wang YC, Huang TL. Screening of anti-Helicobacter pylori herbs deriving from Taiwanese folk medicinal plants. FEMS Immunol. Med. Microbiol. 2005; 43(2): 295-300.

9. Bleves S, Viarre V, Salacha R, Michel GPF, Filloux A, Voulhoux R. Protein secretion systems in Pseudomonas aeruginosa: A wealth of pathogenic weapons. Int. J. Med. Microbiol. 2010; 300(8): 534543.

10. Wiegand I, Hilpert K, Hancock R. Agar and broth dilution methods to determine the minimal inhibitory concentration (MIC) of antimicrobial substances. Nat. Protoc. 2008; 3: 163-175.

11. Andrews JM. Determination of minimum inhibitory concentrations. J. Antimicrob. Chemother. 2001; 48 (Suppl. S1): 5-16.

12. Eloff JN. Quantification of the bioactivity of plant extracts during screening and bioassay guided fractionation. Phytomedicine 2004; 11(4): 370-371.

13. Delcour AH. Outer membrane permeability and antibiotic resistance. Biochimica et Biophysica Acta - Proteins and Proteomics 2009; 1794(5): 808-816.

14. Nikaido $H$. Antibiotic resistance caused by gram-negative multidrug efflux pumps. Clin. Infect. Dis. 1998; 27(SUPPL.1): S32-S41.

15. Velmurugan S, Viji VT, Babu MM, Punitha MJ, Citarasu T. Antimicrobial effect of Calotropis procera active principles against aquatic microbial pathogens isolated from shrimp and fishes. Asian Pac. J. Trop. Biomed. 2012; 2(2 Suppl.): S812-S817.

16. Jain SC, Pancholi B, Jain R. Antimicrobial, free radical scavenging activities and chemical composition of Peltophorum pterocarpum Baker ex K. Heyne stem extract. Pharma Chem. 2012; 4(5): 2073-2079.
17. Dhankhar S, Kumar M, Ruhil S, Balhara M, Chhillar AK. Analysis toward innovative herbal antibacterial \& antifungal drugs. Recent Pat. Anti-Infect. Drug Discovery 2012; 7(3): 242-248.

18. Fernandes CP, Corrêa AL, Lobo JFR, Caramel OP, De Almeida FB, Castro ES, Souza KFCS, Burth $P$, Amorim LMF, Santos MG, et al. Triterpene esters and biological activities from edible fruits of manilkara subsericea (Mart.) dubard, sapotaceae. Biomed Res Int 2013; 2013: 1-7.

19. Koz'minykh VO, Belyaev AO, Koz'minykh EN, Bukanova $E V$, Odegova TF. Synthesis and antimicrobial activity of 2-(2,4-dinitrophenylhydrazono)-4- oxobutanoic acids and related 3-bromo derivatives. Pharm. Chem. J. 2004; 38(7): 368-372.

20. Sanseera $D$, Niwatananun $W$, Liawruangrath $S$, Baramee A, Khantawa B, Pyne SG, Liawruangrath $B$. Comparison of Chemical constituents and antibacterial activities and antioxidant activities of the essential oil from leaves and fruits of Bridelia retusa (L.) A. Juss. J. Sci. Ind. Res. 2012; 71(11): 733-739.

21. McNeil MJ, Porter RBR, Williams LAD. Chemical composition and biological activity of the essential oil from Jamaican Cleome serrata. Nat. Prod. Commun. 2012; 7(9): 1231-1232.

22. Chitra S, Paul N, Muthusubramanian S, Manisankar $P$, Yogeeswari $P$, Sriram D. A facile synthesis of carbocycle-fused mono and bis-1,2,3-selenadiazoles and their antimicrobial and antimycobacterial studies. Eur. J. Med. Chem. 2011; 46(11): 5465-5472.

23. Gul HI, Sahin F, Gul M, Ozturk S, Yerdelen KO. Evaluation of antimicrobial activities of several Mannich bases and their derivatives. Arch. Pharm. 2005; 338(7): 335-338.

24. Sonenshein AL, Hoch JA, Losick R (1993) Bacillus Subtilis and Other Gram-Positive Bacteria: Biochemistry, Physiology, and Molecular Genetics (American Society for Microbiology).

25. Gale EF, Epps HMR. Studies of bacterial amino-acid decarboxylases. Biochem. J. 1944; 38(3): 232-242.

26. Myasnikov AG, Simonetti A, Marzi S, Klaholz BP. Structure-function insights into prokaryotic and eukaryotic translation initiation. Curr. Opin. Struct. Biol. 2009; 19(3): 300-309.

27. Hogg T, Mesters JR, Hilgenfeld R. Inhibitory mechanisms of antibiotics targeting elongation factor Tu. Curr. Protein Pept. Sci. 2002; 3(1): 121-131.

28. Wolf $\mathrm{H}$, Chinali $\mathrm{G}$, Parmeggiani A. Kirromycin, an inhibitor of protein biosynthesis that acts on elongation factor Tu. Proc. Natl. Acad. Sci. U. S. A. 1974; 71(12): 4910-4914.

29. Sibbald MJJB, Ziebandt AK, Engelmann S, Hecker M, De Jong A, Harmsen HJM, Raangs GC, Stokroos I, Arends JP, Dubois JYF, et al. Mapping the pathways to staphylococcal pathogenesis by comparative secretomics. Microbiol. Mol. Biol. Rev. 2006; 70(3): 755-788. 
Wong et al

30. Berube BJ, Wardenburg JB. Staphylococcus aureus $\alpha$ -

1140-1166.

toxin: Nearly a century of intrigue. Toxins 2013; 5(6): 